\title{
Application of multi-isotope ratios to study the source and quality of urban groundwater in Metro Manila, Philippines
}

\author{
Takahiro Hosono $^{1}{ }^{*}$, Fernando Siringan ${ }^{2}$, Tsutomu Yamanaka ${ }^{3}$, Yu Umezawa ${ }^{4}$, Shin-ichi \\ Onodera $^{5}$, Takanori Nakano ${ }^{6}$, Makoto Taniguchi ${ }^{6}$ \\ ${ }^{1}$ Priority Organization for Innovation and Excellence, Kumamoto University, 2-39-1 Kurokami, \\ Kumamoto 860-8555, Japan \\ 2 Marine Science Institute, University of the Philippines, Diliman, Quezon City 1101, \\ Philippines \\ ${ }^{3}$ Terrestrial Environment Research Center, University of Tsukuba, Tsukuba, Ibaraki 305-8577, \\ Japan \\ ${ }^{4}$ Faculty of Fisheries, Nagasaki University, 1-14 Bunkyo-machi Nagasaki, 852-8521, Japan \\ ${ }^{5}$ Graduate School of Integrated Arts and Sciences, Hiroshima University, 1-7-1 Kagamiyama, \\ Higashi-Hiroshima, Hiroshima 739-8521, Japan \\ ${ }^{6}$ Research Institute for Humanity and Nature, 457-4 Motoyama Kamigamo, Kita-ku, Kyoto \\ 603-8047, Japan \\ *Corresponding author \\ Email address: hosono@kumamoto-u.ac.jp
}

\begin{abstract}
To characterize water quality in terms of dissolved elements and to investigate both the origin of the water and the source and behavior of groundwater contaminants in Metro Manila, thirty-three water (groundwater and surface water) samples were analyzed for ion and element concentrations, hydrogen and oxygen isotope ratios $\left(\delta \mathrm{D}-\mathrm{H}_{2} \mathrm{O}\right.$ and $\left.\delta^{18} \mathrm{O}-\mathrm{H}_{2} \mathrm{O}\right)$, sulfate isotope ratios $\left(\delta^{34} \mathrm{~S}_{-} \mathrm{SO}_{4}{ }^{2-}\right.$ and $\left.\delta^{18} \mathrm{O}-\mathrm{SO}_{4}{ }^{2-}\right)$, and strontium isotope ratio $\left({ }^{87} \mathrm{Sr} /{ }^{86} \mathrm{Sr}\right)$. The chemical measurements showed that the primary important environmental concerns within Metro Manila are groundwater salinization for both shallow and deep aquifers, and arsenic concentrations (up
\end{abstract}


to $22.5 \mu \mathrm{g} / \mathrm{L}$ ) in shallow groundwaters. Comparison of sulfate and strontium isotope values with possible source materials revealed that contamination by man-made materials such as fertilizers and detergents are present in some shallow groundwaters. Shallow groundwater having higher $\delta \mathrm{D}-\mathrm{H}_{2} \mathrm{O}$ and $\delta^{18} \mathrm{O}-\mathrm{H}_{2} \mathrm{O}$ values (av. $-44 \%$ o $\pm 5.6 \%$ and $-6.8 \%$ o $\pm 0.6 \%$, respectively, $n=15$ ) than deep groundwater (av. $-48 \% \pm 4.4 \%$ and $-7.4 \%$ o $\pm 0.7 \%$, respectively, $n=7$ ) suggests that the origins of $\mathrm{H}_{2} \mathrm{O}$ in both groundwaters are different from each other. Since the mixing of shallow and deep groundwater is not commonly occurring under Metro Manila, the contaminants in the shallow aquifers are unlikely to be transported into the deep aquifers. Sulfate reduction by bacterial activity was observed for some groundwaters, resulting in a maximum elevation in $\delta^{34} \mathrm{~S}^{-\mathrm{SO}_{4}}{ }^{2-}$ values of around $10 \%$. By using sulfate isotope ratios as an indicator of changes in redox conditions and strontium isotope ratio as a source indicator, it was shown that arsenic was dissolved from unconsolidated sedimentary deposits of volcanic origin which enclose shallow unconfined aquifers, but was not the result of changes in redox conditions. The study demonstrated that multi-isotope ratios are useful for evaluating water quality problems in urban groundwaters.

Keywords: groundwater, water quality, arsenic, sulfate isotope ratios, strontium isotope ratio

\section{Introduction}

Deterioration of the groundwater quality has become a serious environmental problem in Asian metropolitan cities undergoing economic growth (Foster, 2003). In terms of dissolved elements of environmental concern, groundwater salinization due to overpumping, nitrate pollution from urban wastes, and naturally occurring arsenic pollution are the major problems reported for these areas (Arthurton, 1998; Mukherjee et al., 2006; Umezawa et al., 2009). However, few studies have investigated detailed sources of contaminants and the hydrogeochemical processes that produce groundwater with specific pollution constituents, including within Metro Manila, Philippines (ADB, 2006).

The hydrogen and oxygen isotope ratios of water $\left(\delta \mathrm{D}-\mathrm{H}_{2} \mathrm{O}\right.$ and $\left.\delta^{18} \mathrm{O}-\mathrm{H}_{2} \mathrm{O}\right)$ have been widely used for elucidating the source(s) of groundwaters and the mixing of different source waters (Clark and Fritz, 1997). Stable isotope ratios for nitrate $\left(\delta^{15} \mathrm{~N}_{-} \mathrm{NO}_{3}{ }^{-}\right.$and $\left.\delta^{18} \mathrm{O}-\mathrm{NO}_{3}{ }^{-}\right)$have been applied to understand the sources of nitrate pollution and denitrification processes that may take place in aquifers (Kendall and McDonnell, 1998; Cook and Herczeg, 2000). Although dissolved sulfate is not a hazardous ion in natural water systems, sulfate can be derived from man-made materials such as air pollution, agrochemicals and sewage. Sulfate isotope ratios $\left(\delta^{34} \mathrm{~S}^{-\mathrm{SO}_{4}}{ }^{2-}\right.$ and $\left.\delta^{18} \mathrm{O}^{-\mathrm{SO}_{4}}{ }^{2-}\right)$ have been used to elucidate the pollution sources of dissolved sulfate (Robinson and Bottrell, 1997; Torssander et al., 2006; Otero et al., 2008). 
Arsenic in aquifers originates both as sulfide minerals and complexes with organic and inorganic materials which usually dissolve into groundwater as the result of redox changes and water and rock interactions (Plant et al., 2005). Naturally occurring arsenic tends to be dissolved in groundwater in anaerobic environments, where sulfate reduction can occur (Plant et al., 2005). Since sulfate isotope values are also good indicators for investigating the occurrence of sulfate reduction by bacterial activity in aquifers (Moncaster et al., 2000; Dogramaci et al., 2001; Spence et al., 2001), these isotopes can be applied to evaluate whether redox changes are responsible for groundwater arsenic pollution (Stüben et al., 2003; Lipfert et al., 2007).

The strontium isotope ratio $\left({ }^{87} \mathrm{Sr} /{ }^{86} \mathrm{Sr}\right)$ can be used as a tracer of dissolved minerals (Borg and Banner, 1996; Hosono et al., 2009), because dissolved strontium generally originates in geological constituents such as soils and minerals (Åberg et al., 1989; Négrel et al., 1993; Semhi et al., 2000), and is not affected by fractionation processes during previous biogeochemical processes. This makes ${ }^{87} \mathrm{Sr} /{ }^{86} \mathrm{Sr}$ ratio a good tracer of the rock types which interact with groundwater, except in agricultural areas where significant amounts of agrochemicals contribute to the water quality change (Böhlke and Horan, 2000). If groundwater contains arsenic of geological origin, the strontium isotope ratio can be a good indicator for evaluating the underlying geology.

The majority of aquifers in Metro Manila are developed in widely distributed Plio-Pleistocene sedimentary layers with a maximum depth of around $300 \mathrm{~m}$ (JICA, 1992). Groundwater salinization has been recognized in Metro Manila since at least the early 1960s and its distribution was fully investigated in 1991 (JICA, 1992). This report indicated that, by the year 1991, the majority of aquifers in the coastal areas were significantly affected by saline water intrusion due to excess pumping during the period of urbanization. However, further investigations have not been carried out. Umezawa et al. (2009), in their nitrate isotopic study of Metro Manila groundwater, suggested that the majority of nitrate originated from municipal sewage with a lesser contribution from local agricultural activities and that the accumulated groundwater nitrate concentrations are attenuated due to the occurrence of denitrification. Consequently, Umezawa et al. (2009) concluded that groundwater nitrate pollution in Metro Manila with $\mathrm{NO}_{3}{ }^{-}$concentrations up to $19.4 \mathrm{mg} / \mathrm{L}$ but with an average concentration of $1.8 \mathrm{mg} / \mathrm{L}$ ( $n=21)$ is not currently a serious concern. Naturally occurring arsenic contamination is becoming increasingly recognized in Asian countries (Mukherjee et al., 2006). However, scientific reports on arsenic pollution are scarce in the region.

The major objectives of this study are: (1) to investigate fundamental problems of groundwater quality in the Metro Manila region in terms of dissolved elements, (2) to evaluate the contribution of man-made materials to groundwater quality by using sulfate and strontium isotopic tracers, and (3) to investigate the source of arsenic and its pollution mechanism by 
using sulfate and strontium isotopic indicators. The results represent a case study showing the usefulness of multi-isotope ratios in developing a comprehensive understanding of groundwater contamination in urban subsurface environments.

\section{The study area}

Metro Manila, the capital region of the Philippines, is located between Manila Bay and Laguna de Bay in the southern part of Luzon (Fig. 1). The Metro Manila jurisdiction (Manila City and the surrounding urbanized area) is highly urbanized (Fig. 1b; MMDA and IAURIF, 1997) and has a population of approximately 11.6 million in 2008 covering an area of $636 \mathrm{~km}^{2}$. The city is developed on both the narrow coastal plains with an elevation of 0 to $10 \mathrm{~m}$ and on inner hilly areas with an elevation of 20 to $70 \mathrm{~m}$. A mountain range with altitudes around 1,000 $\mathrm{m}$ is on the northeast side of the city. The Pasig River flows as a major river through Metro Manila, crossing between Manila Bay and Laguna de Bay (Fig. 1a). The exchange of sea water and lake water is commonly observed in this river. The area has a tropical monsoon climate with an average annual temperature and precipitation of $27^{\circ} \mathrm{C}$ and $1970 \mathrm{~mm}$, respectively (http://www.weatherbase.com/). It has a distinct dry season from November to May and a wet season from June to October.

Geological units underlying the study area are mainly Tertiary basement rocks, Plio-Pleistocene sedimentary rocks of the Guadalupe Formation, which is widely exposed in the central hilly areas, and overlying coastal alluvium 10 to $60 \mathrm{~m}$ thick (Fig. 1a; JICA, 1992). The Tertiary basement rocks consist of consolidated, relatively impermeable clastic and volcanic rocks. These rocks generally yield very poor water or form aquifuges. The Guadalupe Formation is composed of alternating beds of detrital sediments of volcanic origin such as tuffaceous sandstone, conglomerate, mudstone, and coarse tuff. The sedimentary layers in the study area generally strike $\mathrm{NE}$ with a dip less than $10^{\circ} \mathrm{W}$ and form good aquifers surrounded by impermeable basement rocks. Groundwater is situated within either deeper confined aquifers developed in the sedimentary layers of the Guadalupe Formation or shallower unconfined aquifers in the unconsolidated alluvial plain (JICA, 1992).

Ebarvia (1997) reported the presence of more than 3,000 deep and shallow wells and 20,000 dug wells in the urbanized area within Metro Manila. A total of 571 million $\mathrm{m}^{3} / \mathrm{y}$ of groundwater is estimated to be supplied for industrial, agricultural, and drinking purposes. This is about $25 \%$ of the total water supply in the city. Unfortunately, no reports present a clear description of the aquifers under Metro Manila. Therefore, groundwater wells are divided in this paper into two groups, based on well depths: shallow groundwater wells 2 to $122 \mathrm{~m}$ deep, and deep groundwater wells 183 to $269 \mathrm{~m}$ deep (Table 1). All shallow groundwater samples were 
collected at dug wells or hand-pumped wells, while the deep groundwater samples were collected at production wells. Although this groundwater classification does not necessarily follow specific aquifer systems, the groundwater origin and its chemistry show good agreement with the well depth as will be described in Section 4. Therefore, we use this classification for later discussion of the groundwater geochemistry.

\section{Samples and analytical methods}

Sampling locations are shown in Fig. 1. The locations were selected so as to avoid areas of heavy industry or factories in order to minimize the possibility of point source contamination. Twenty eight groundwater samples from wells and four river water samples from the Pasig River and its tributary were collected during the period 26-30 May 2006. One rainwater sample was collected during this survey. Major ions, trace elements (As, Cd, and $\mathrm{Pb}$ ), $\delta \mathrm{D}-\mathrm{H}_{2} \mathrm{O}$ and

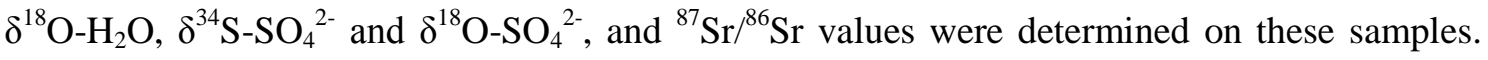
Samples were filtered through $0.2 \mu \mathrm{m}$ cellulose-acetate filters before storing. Filtered samples for trace elements and $\delta^{34} \mathrm{~S}_{-} \mathrm{SO}_{4}{ }^{2-}$ and $\delta^{18} \mathrm{O}-\mathrm{SO}_{4}{ }^{2-}$ analysis were acidified to $\mathrm{pH} 2$ with nitric acid and to $\mathrm{pH} 2.5$ to 3.0 with distilled $6 \mathrm{M} \mathrm{HCl}$, respectively. Dissolved $\mathrm{SO}_{4}{ }^{2-}$ in the acidified samples was collected as $\mathrm{BaSO}_{4}$ by adding $10 \% \mathrm{BaCl}_{2}$.

Three sulfate-bearing chemical fertilizers and four powder-synthetic detergents, which are widely used in Metro Manila, were selected for chemical and sulfate and strontium isotope analyses. $1.0 \mathrm{~g}$ of powdered fertilizer and detergent samples were reacted with $1 \mathrm{~L}$ of distilled water at room temperature for $24 \mathrm{~h}$, following the recommended proportions for actual use. Samples were then filtered through $0.2 \mu \mathrm{m}$ cellulose-acetate filters and processed for chemical and isotopic analysis in the same way as the groundwater samples.

Major ion and trace elements concentrations were measured by ion chromatography at the Research Institute for Humanity and Nature (RIHN) and by inductively coupled plasma emission mass spectrometry at ACTLABS (Canada). The concentrations of $\mathrm{SO}_{4}{ }^{2-}, \mathrm{NO}_{3}{ }^{-}$and As are expressed as the total dissolved ion concentrations as $\mathrm{SO}_{4}{ }^{2-}, \mathrm{NO}_{3}{ }^{-}$and $[\mathrm{As}(\mathrm{III})]+[\mathrm{As}(\mathrm{V})]$, respectively. The $\delta \mathrm{D}-\mathrm{H}_{2} \mathrm{O}$ and $\delta^{18} \mathrm{O}-\mathrm{H}_{2} \mathrm{O}$ and $\delta^{34} \mathrm{~S}_{-} \mathrm{SO}_{4}{ }^{2-}$ and $\delta^{18} \mathrm{O}-\mathrm{SO}_{4}{ }^{2-}$ were determined by stable isotope ratio mass spectrometer (Thermo Finnigan MAT252) at the University of Tsukuba and by continuous-flow gas-ratio mass spectrometer (Thermo Scientific Delta PlusXL) at the University of Arizona. Analytical precisions of $\delta \mathrm{D}-\mathrm{H}_{2} \mathrm{O}, \delta^{18} \mathrm{O}-\mathrm{H}_{2} \mathrm{O}, \delta^{34} \mathrm{~S}^{-\mathrm{SO}_{4}}{ }^{2-}$, and $\delta^{18} \mathrm{O}-\mathrm{SO}_{4}{ }^{2-}$ were $\pm 1 \%$ o, $\pm 0.1 \%$ o, $\pm 0.2 \%$, and $\pm 0.3 \%$ o, respectively. The ${ }^{87} \mathrm{Sr} /{ }^{86} \mathrm{Sr}$ values were determined using a thermal ionization mass spectrometer with static multi-collection (Thermo electron Triton) at RIHN, following the analytical procedure of Na et al. (1995). The ${ }^{87} \mathrm{Sr} /{ }^{86} \mathrm{Sr}$ values were normalized to ${ }^{86} \mathrm{Sr} /{ }^{88} \mathrm{Sr}=0.1194$, and the ${ }^{87} \mathrm{Sr} /{ }^{86} \mathrm{Sr}$ of the NIST-SRM987 throughout this 
study were $0.710240 \pm 0.000006(2 \sigma, n=14)$. All ${ }^{87} \mathrm{Sr} /{ }^{86} \mathrm{Sr}$ data were normalized to a NIST-SRM987 value of 0.710250 . Analytical results are shown in Tables 1 and 2.

\section{Results}

\subsection{Groundwater geochemistry}

The Piper diagram (Fig. 2) shows that most of the river water and groundwaters of the Metro Manila area are of the $\mathrm{Ca}-\mathrm{HCO}_{3}$ or $\mathrm{Na}-\mathrm{HCO}_{3}$ types, whereas $\mathrm{Na}_{2} \mathrm{SO}_{4}-\mathrm{NaCl}$ or $\mathrm{CaSO}_{4}-\mathrm{CaCl}_{2}$ type waters are less common. Most of the shallow groundwaters are of the Ca- $\mathrm{HCO}_{3}$ type except for four samples (M4, 16, 19, and 26), while the deep groundwaters tend to be of the Na-HCO 3 type (Fig. 2). Groundwater becomes enriched in monovalent cations such as $\mathrm{Na}^{+}$and $\mathrm{K}^{+}$compared with the divalent cations such as $\mathrm{Ca}^{2+}$ and $\mathrm{Mg}^{2+}$ with time, indicating cation exchange reactions with aquifer minerals (Appelo and Postma, 2005). A longer residence time of deep groundwater might create this chemical differentiation. These results correspond well with a previous report (JICA, 1992).

Four shallow groundwater samples from a coastal area (M4, 16, 19, and 26; Fig. 1 for their locations) and one deep groundwater sample near the mouth of the Pasig River (M31) are categorized as being of the $\mathrm{Na}_{2} \mathrm{SO}_{4}-\mathrm{NaCl}$ type and $\mathrm{CaSO}_{4}-\mathrm{CaCl}_{2}$ type with significantly high electrical conductivities (up to $1,000 \mu \mathrm{S} / \mathrm{cm}$ ) (Table 1 and Fig. 2). JICA (1992) reported that in the coastal area of Manila Bay and the plains area of the Pasig River, groundwater salinization started after the 1960s with electrical conductivities increasing to over 1,000 $\mu \mathrm{S} / \mathrm{cm}$ (Fig. 3a). Our data shows a similar distribution pattern of high electric conductivity to that of the JICA (1992) report (Fig. 3a), suggesting that groundwater salinization is still a local concern.

Nitrate concentrations of the groundwater samples varied between 0.5 and $145 \mathrm{mg} / \mathrm{L}$ (Table 1); however, except for sample M16, they are much lower than the recommended WHO limit of $44 \mathrm{mg} / \mathrm{L}$ (Table 1). The highest nitrate concentrations are observed in the shallow groundwaters (Table 1; Fig. 3b). Umezawa et al. (2009) suggested that elevated nitrate ion concentrations in shallow aquifers are caused by leakage of municipal sewage through sewer pipes and locally by agricultural waste water drainage and that accumulated nitrate ions are chemically reduced by denitrification. Therefore, groundwater nitrate pollution under Metro Manila is not a serious issue at the present time (Umezawa et al., 2009). Some high nitrate concentrations were found in the Pasig River samples (21 and 70 mg/L for M13 and 14, respectively). The Pasig River is in a much more aerobic condition than the groundwaters, probably reducing the possibility of denitrification reducing nitrate concentrations.

Arsenic concentrations in groundwater samples range between 1.1 and $22.5 \mu \mathrm{g} / \mathrm{L}$ (Table 1). 
This range is higher than that of rainwater and river water samples $(0.4-4.4 \mu \mathrm{g} / \mathrm{L})$, water reacted with fertilizers (0.3-7.2 $\mu \mathrm{g} / \mathrm{L})$ and detergent samples $(0.3-4.2 \mu \mathrm{g} / \mathrm{L})$ (Tables 1 and 2). Around $30 \%$ of the analyzed groundwater samples have arsenic concentrations exceeding $10 \mu \mathrm{g} / \mathrm{L}$, which is the maximum recommended WHO standard concentration in waters. Importantly, the shallow groundwaters tend to be more enriched in arsenic than the deep groundwaters (Table 1 and Fig. 3c). Dissolved cadmium and lead concentrations in the water samples were far lower than the WHO limit of $10 \mu \mathrm{g} / \mathrm{L}$ (Table 1), although suspended particles were not analyzed in this study.

\subsection{Isotope ratios}

The hydrogen and oxygen isotope values of analyzed groundwater samples display compositional ranges between $-34 \%$ and $-52 \%$ for $\delta \mathrm{D}-\mathrm{H}_{2} \mathrm{O}$ and $-6.0 \%$ and $-7.9 \%$ for $\delta^{18} \mathrm{O}-\mathrm{H}_{2} \mathrm{O}$ (Table 1). In Fig. 4, groundwater samples are plotted linearly along the fitted line of the precipitation data for Metro Manila. The deep groundwater tends to have relatively lower hydrogen and oxygen isotope values (av. $-48 \% \pm 4.4 \%$ and $-7.4 \%$ o $\pm 0.7 \%$ o, respectively, $n=7$ ), while the shallow groundwater tends to have higher isotope values (av. $-44 \% \pm 5.6 \%$ and $-6.8 \%$ o $\pm 0.6 \%$, respectively, $n=15$ ), though some are overlapping. The $\delta^{18} \mathrm{O}-\mathrm{H}_{2} \mathrm{O}$ values of groundwater decrease with increasing well depth ( $\mathrm{m}$ from the surface) (correlation coefficient $=$ $0.73)$.

Sulfur and oxygen isotope values of dissolved sulfate ions $\left(\delta^{34} \mathrm{~S}_{-} \mathrm{SO}_{4}{ }^{2-}\right.$ and $\left.\delta^{18} \mathrm{O}_{-} \mathrm{SO}_{4}{ }^{2-}\right)$ in groundwater samples vary from $-1.8 \%$ o to $+23.9 \%$ and from $+5.5 \%$ o to $+16.6 \%$, respectively. The range of the analyzed $\delta^{18} \mathrm{O}-\mathrm{SO}_{4}{ }^{2-}$ values of groundwaters are relatively higher than those of river waters $(+6.0 \%$ o to $+10.0 \%$ ). There are no clear compositional differences between the shallow and deep groundwaters (Table 1). Sulfate isotope compositions of water after reaction with fertilizers display narrow and lower ranges $\left(\delta^{34} \mathrm{~S}_{-} \mathrm{SO}_{4}{ }^{2-}=-0.2 \%\right.$ to $+0.8 \%$ and $\delta^{18} \mathrm{O}^{-} \mathrm{SO}_{4}{ }^{2-}=$ $+9.9 \%$ o to $+10.4 \%$ o $)$ than those of water reacted with detergents $\left(\delta^{34} \mathrm{~S}^{-\mathrm{SO}_{4}{ }^{2-}=+13.5 \% \text { o to }}\right.$ $+24.9 \%$ and $\delta^{18} \mathrm{O}_{-} \mathrm{SO}_{4}{ }^{2-}=+12.4 \%$ o to $+17.8 \%$ ) (Table 2 ).

The ${ }^{87} \mathrm{Sr} /{ }^{86} \mathrm{Sr}$ ratios of groundwater samples are in a range between 0.70447 and 0.70645 . Downstream waters of the Pasig River (M13 and 14) show higher Sr isotope ratios (0.70790 and 0.70895, respectively) than those of upstream waters (M11 and 12; 0.70566 and 0.70544 , respectively), suggesting that a strontium source with a higher isotopic ratio is contributing to the values for the downstream river waters. The $\mathrm{Sr}$ isotope measurements for possible source materials gave results only for two fertilizer samples (MNLF3 and MNLF4) with ${ }^{87} \mathrm{Sr} /{ }^{86} \mathrm{Sr}$ values of 0.70589 and 0.70697 , respectively (Table 2). 


\section{Discussion}

\subsection{Origin of groundwater}

The position of $\delta \mathrm{D}-\mathrm{H}_{2} \mathrm{O}$ and $\delta^{18} \mathrm{O}-\mathrm{H}_{2} \mathrm{O}$ compositions of groundwater samples when plotted along the local precipitation line in Fig. 4, suggests that these groundwaters originate from rain water. In general, the $\delta \mathrm{D}-\mathrm{H}_{2} \mathrm{O}$ and $\delta{ }^{18} \mathrm{O}-\mathrm{H}_{2} \mathrm{O}$ values of the precipitation shift to lighter compositions with increasing altitude (Clark and Fritz, 1997). Shallow groundwaters have isotope compositions similar to the weighted mean isotope compositions of rain water in Metro Manila that has a measured composition of $\delta \mathrm{D}-\mathrm{H}_{2} \mathrm{O}=-45 \%$ and $\delta^{18} \mathrm{O}-\mathrm{H}_{2} \mathrm{O}=-6.8 \%$ o $(n=84)$ calculated with data from 1961 to 2003 obtained from the Global Network for Isotopes in Precipitation (GNIP) dataset (available at http://isohis.iaea.org) and those of the tributary of the Pasig River (M11 and 12) (Fig. 4). This isotopic similarity implies that these shallow groundwaters are derived by direct infiltration of rainwater and/or via river water.

There is a large isotopic gap between some shallow groundwater (M16) and deep groundwater (M9) samples that may be explained by different processes. If this isotope difference is considered to be caused by the different altitude of the recharge area, it can be estimated roughly, by using a global mean lapse rate of $-0.28 \% / 100 \mathrm{~m}$ (Poage and Chamberlain, 2001), that deep groundwater might be recharged at elevations around $680 \mathrm{~m}$. Unfortunately, evaluation of altitude effects have rarely been examined in tropical regions. Then, considering the maximum variation of lapse rate among the areas of the world $(-0.15 \%$ o to $-0.5 \% / 100 \mathrm{~m}$; Clark and Fritz, 1997), recharge elevations of the deep groundwaters are calculated to be between 380 and $1267 \mathrm{~m}$. These results support the idea that the majority of deep groundwater under Metro Manila is recharged along the northeast mountainous area where altitudes reach $1,500 \mathrm{~m}$. Evaporation from aquifer waters seems to not be a fundamental factor creating the observed compositional variation (Clark and Fritz, 1997). Outcropping rocks of the Guadalupe Formation along the northeast mountainous area, with its $\mathrm{NE}$ strike and $10^{\circ} \mathrm{W}$ dip, may recharge the groundwater by transporting precipitation downwards along the bedding plane.

The water samples from the Pasig River (M13 and 14) show higher isotopic ratios than the other water samples (Table 1 and Fig. 4) reflecting the intrusion of sea water with higher isotope ratios into the river. However, the estimated mixing ratios of sea water into the fresh river water (M11) exceed $50 \%$ (Fig. 4) which is much bigger than that estimated from the chemistry and sulfate isotope data (5-27\%) as discussed later. Therefore, increasing isotope values in M13 and 14 might be partly attributed to evaporation of water in the Pasig River. One deep groundwater sample (M20) shows higher isotope values than the other measured samples (Fig. 4) while some shallow groundwater samples (M2, 4, 6, and 10) display lower values. Since these shallow 
groundwater samples were collected from relatively deep wells between 46 and $122 \mathrm{~m}$, waters recharged in the mountain areas are probably the source of these groundwaters. In contrast, the mixing of shallow groundwater with higher isotope values with deep groundwater may have occurred at the M20 sampling site.

\subsection{Pollution assessment using sulfate isotope ratios}

The results of groundwater geochemistry indicate that salinization and arsenic concentrations are the most important groundwater quality concerns for Metro Manila, with respect to dissolved inorganic components. Although nitrate pollution does not represent a significant health risk for humans at the present time, groundwater quality is certainly affected by human activities. Consideration of the factors controlling sulfate concentrations and the use of sulfate isotopic tracers allow the contribution of man-made materials to be clarified.

Sulfate ions in the groundwater could originate from various sources including sea water, soils, dissolution of sulfate minerals, oxidation of sulfide minerals, and anthropogenic materials such as chemical fertilizers, synthetic detergents, and polluted precipitation. Diagrams of

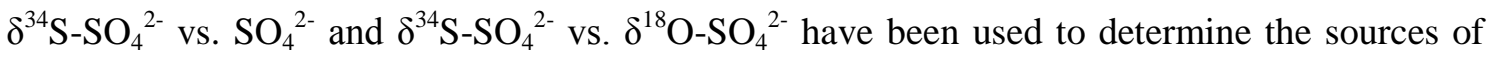
sulfate and the occurrence of sulfate reduction (Robinson and Bottrell, 1997; Otero and Soler, 2002; Nakano et al., 2005; Li et al., 2006; Torssander et al., 2006; Brenot et al., 2007; Hosono et al., 2007, 2009).

Rivers with associated small populations on the mountain slopes bordering the eastern side of Metro Manila are least likely to be affected by human activity. Also, the contribution of saline water to river water should be negligible in this area. Therefore, we consider that these waters represent recharge waters showing no effects of significant contamination from the possible sulfate sources. Since the Pasig River tributary waters (M11 and 12) are more enriched in sulfate ions $(12.8 \mathrm{mg} / \mathrm{L})$ than rainwater $(\mathrm{M} 15 ; 3.0 \mathrm{mg} / \mathrm{L})$, the majority of dissolved sulfate in upstream water is considered to be of natural origin from soils and minerals. Samples M11 and M12 show similar $\delta^{34} \mathrm{~S}_{-} \mathrm{SO}_{4}{ }^{2-}$ compositions at $+5.3 \%$ and $+9.6 \%$, respectively, which are well within values reported for soil sulfates (Fig. 6). However, their $\delta^{18} \mathrm{O}_{-} \mathrm{SO}_{4}{ }^{2-}$ compositions are slightly but clearly higher than those of soil sulfates, suggesting the possible contribution of anthropogenic sulfate with relatively high $\delta^{18} \mathrm{O}-\mathrm{SO}_{4}{ }^{2-}$ compositions (Fig. 6). Therefore, it is assumed that the mountainous Pasig River tributary waters are affected already by the local use of chemical fertilizers and synthetic detergents prior to reaching the alluvial plains area. The mixing of sea water into the Pasig River water (M 13 and 14) is confirmed in Figs. 5 and 6, with mixing ratios estimated to be ca. $5 \%$ and $27 \%$, respectively.

Some groundwater samples have higher sulfate concentrations than the $12.8 \mathrm{mg} / \mathrm{L}$ of the 
Pasig River tributary waters (Table 1). In Figs. 5 and 6, groundwater samples form two clusters, A and B. Cluster A shows increasing sulfate concentrations (up to $38.4 \mathrm{mg} / \mathrm{L}$ ) with decreasing $\delta^{34} \mathrm{~S}^{-\mathrm{SO}_{4}}{ }^{2-}$ and increasing $\delta^{18} \mathrm{O}-\mathrm{SO}_{4}{ }^{2-}$ values (up to $+13.7 \%$ ), along the mixing line connecting the composition of upstream water (M11) and chemical fertilizers. Therefore, it is possible that sulfate enrichment in the groundwaters in cluster A, i.e., for M27, is caused partly by the application of chemical fertilizers in local agriculture. For M10 which plots close to Cluster A, because of its low $\delta^{34} \mathrm{~S}_{-} \mathrm{SO}_{4}{ }^{2-}$ and $\delta^{18} \mathrm{O}^{-} \mathrm{SO}_{4}{ }^{2-}$ values, enrichment of sulfate ions (56.2 $\mathrm{mg} / \mathrm{L}$ ) is possibly due to oxidation of reduced inorganic sulfur compounds (such as pyrite) in the aquifer (Krouse and Mayer, 2000).

Cluster B shows increasing sulfate concentrations (up to $35.4 \mathrm{mg} / \mathrm{L}$ ) with increasing $\delta^{34} \mathrm{~S}^{-} \mathrm{SO}_{4}{ }^{2-}$ (up to $+14.4 \%$ ) and $\delta^{18} \mathrm{O}-\mathrm{SO}_{4}{ }^{2-}$ values (up to $+16.6 \%$ ), along the mixing line connecting the composition of upstream water and synthetic detergents or sea water (Figs. 5 and 6). It is difficult for the Cluster B samples to distinguish the proportion of sulfate contribution from the three possible source materials (soils, synthetic detergents, and sea water) because of their compositional overlaps. However, based on Figs. 5 and 6, the sulfate enrichment in groundwater sample M8 might be caused mainly by the contribution of synthetic detergents as laundry is usually done near the wells. However, this effect is less obvious for the groundwater samples M6, 7 and 33 (Fig. 6). In these samples the measured sulfate concentration may have been derived partly from sea water.

\subsection{Determination of sulfate reduction by means of sulfate isotope ratios}

As previously mentioned, samples M4 and 26 are affected by the contribution of sea water. However, plots for these samples in Fig. 5 deviate at the right side of the sea water mixing line, suggesting the occurrence of sulfate reduction by bacterial activity (Thode, 1991). Similarly, most of the other samples having $\delta^{34} \mathrm{~S}_{-} \mathrm{SO}_{4}{ }^{2-}$ values greater than $+15.0 \%$ have relatively low $\mathrm{SO}_{4}{ }^{2-}$ concentrations, with a minimum value of $5.7 \mathrm{mg} / \mathrm{L}$ (Fig. 5). These samples are also characterized by high $\delta^{18} \mathrm{O}-\mathrm{SO}_{4}{ }^{2-}$ values up to $+16.6 \%$ for a given $\delta^{34} \mathrm{~S}_{-}-\mathrm{SO}_{4}{ }^{2-}$ (Fig. 6). Increases in both $\delta^{34} \mathrm{~S}_{-} \mathrm{SO}_{4}{ }^{2-}$ and $\delta^{18} \mathrm{O}-\mathrm{SO}_{4}{ }^{2-}$ values with decreasing $\mathrm{SO}_{4}{ }^{2-}$ concentrations is typically associated with sulfate reduction by bacterial activity (Dogramaci et al., 2001; Grassi and Cortecci et al., 2005; Yamanaka and Kumagai, 2006). Therefore, these groundwater samples are considered to have shifted from their original compositions (shown by the enclosed fields in Figs. 5 and 6) to the present fields. Considering this isotopic increase from the original to the present compositions, the maximum extent of the elevation in $\delta^{34} \mathrm{~S}_{-} \mathrm{SO}_{4}{ }^{2-}$ values by a bacterial effect would be around 10\%o (Fig. 5).

Both shallow (M4, 22, 24, 25, 26 and 32) and deep (M1, 3, 5, 28, 30 and 31) groundwaters 
are affected by sulfate reduction (Figs. 5 and 6). Moreover, clear distribution patterns of the occurrence of sulfate reduction were not apparent (see Fig. 1 for the sample distribution). This suggests that the sulfur reducing process in Metro Manila groundwaters is associated with geological and biological properties at a local scale.

Sulfate reducing processes deduced from sulfate isotope ratios in underground environments are sometimes associated with the dissolution of arsenic into the groundwater (Stüben et al., 2003; Lipfert et al., 2007). However, our results do not show any clear relationships between arsenic concentrations and the occurrence of sulfate reduction. Low arsenic concentrations in the chemical fertilizers and synthetic detergents (Table 2) suggest that they are not the source of the high arsenic concentrations in the groundwater. Moreover, all samples were collected in areas away from heavy industry or factories. Arsenic dissolution from sedimentary deposits into groundwater, not related to redox controls, is the most likely source of arsenic pollution in the Metro Manila region.

\subsection{Source of arsenic and its pollution mechanism with strontium isotope analysis}

In Asian countries, high concentrations of naturally occurring arsenic are found most frequently in young alluvial and deltaic deposits with large amounts of fine grained detrital sediments together with fresh organic matter, except in mineralized or mining areas (Plant et al., 2005; Mukherjee et al., 2006; Polizzotto et al., 2008). In addition, much higher concentrations of arsenic commonly occur in pore waters extracted from unconsolidated sediments than in surface waters or groundwaters (Plant et al., 2005). Dissolution of arsenic from arsenic-bearing sedimentary deposits via pore waters might be a cause of arsenic concentrations for Metro Manila groundwater.

In general, groundwater in natural environments is in $\mathrm{Sr}$ isotopic equilibrium with aquifer sediments through cation exchange reactions (Katz and Bullen, 1996; Frost and Toner, 2004; Gosselin et al., 2004; Musgrove and Banner, 2004), except in places where heavy contamination or sea water intrusion occurs. For example, in Florida this equilibrium has been reported to be achieved within a few to ten years (Bullen et al., 1996). It has also been shown in Seoul City that groundwater in the fissure zone of crystalline granitic or metamorphic rocks achieved $\mathrm{Sr}$ isotopic equilibrium regardless of short residence times (30 to $40 \mathrm{yr}$ ) (Hosono et al., 2009). Because rocks and minerals are the primary sources, the majority of strontium in groundwater is derived from geological materials. There may also be agricultural contributions from long use of agrochemicals (Böhlke and Horan, 2000) or from prolonged application of synthetic fertilizers neutralized with carbonate minerals (Hosono et al., 2007).

Groundwaters collected in Metro Manila are linked to the Guadalupe Formation of 
sedimentary rocks from volcanic origins or alluvium deposits of the same origin. The ${ }^{87} \mathrm{Sr} /{ }^{86} \mathrm{Sr}$ values of these volcanic rocks of the Taal volcanic group range between 0.704 and 0.705 (Castillo, 1996). Groundwater samples with a low $\delta^{34} \mathrm{~S}_{-} \mathrm{SO}_{4}{ }^{2-}$ range $(+3 \%$ o to $+10 \%$ ), with sulfate ions basically of geological origin, display ${ }^{87} \mathrm{Sr} /{ }^{86} \mathrm{Sr}$ values of 0.704 to 0.705 (Fig. 7). It is clear from these isotopic signatures that the strontium, as well as the sulfate in these groundwaters, is largely derived from volcanic rocks in contact with the aquifers.

Some water samples show higher ${ }^{87} \mathrm{Sr} /{ }^{86} \mathrm{Sr}$ values than 0.705 (Fig. 7). Therefore, the contribution of other materials with high ${ }^{87} \mathrm{Sr} /{ }^{86} \mathrm{Sr}$ values should be considered. Three possible sources are: sedimentary basement rocks, sea water with a ${ }^{87} \mathrm{Sr} /{ }^{86} \mathrm{Sr}$ value of 0.70916 (Banner, 2004), and man-made materials with higher ${ }^{87} \mathrm{Sr} /{ }^{86} \mathrm{Sr}$ value than 0.706 (Fig. 7). However, the sample from the Pasig River tributary (M11), which has had contact with Tertiary basement rocks, yielded a ${ }^{87} \mathrm{Sr} /{ }^{86} \mathrm{Sr}$ value of 0.70566 , and this value is lower than that for groundwater samples M6, 7, 27, 32 and 33 (Fig. 7). Therefore, the contribution of the sedimentary basement rocks does not explain the elevated ${ }^{87} \mathrm{Sr} /{ }^{86} \mathrm{Sr}$ values in the groundwater.

In Fig. 7, the strontium and sulfate isotope ratios for river waters (M13 and 14) and groundwaters (M6, 7, 32 and 33) tend to increase towards detergent or sea water composition, except for the samples affected by sulfate reduction. This trend supports the interpretation from sulfate isotope ratios that the groundwater sample M8 and river water samples M13 and 14 are affected significantly by the contribution of detergents and sea water, respectively. However, the source of strontium for the rest of the water samples might be a mixture of three components (volcanic rocks, sea water, and detergents). Sea water mixing for groundwater samples M4 and 26 is confirmed by their increasing ${ }^{87} \mathrm{Sr} /{ }^{86} \mathrm{Sr}$ ratios (Fig. 7). Sample M27 is plotted in Fig. 7 on the compositional field of fertilizers used in the Metro Manila region. A relatively high nitrate concentration (15.7 mg/L; Table 1) together with this isotopic evidence indicates that fertilizer input is responsible for the deterioration of groundwater quality in this area.

Potentially, sea water cannot be a source of the arsenic because of its generally low concentration of $<1.5 \mu \mathrm{g} / \mathrm{L}$ (Smedley and Kinniburgh, 2002). Geochemical analysis of fertilizers and detergents (Table 2) also suggests that these are not potential sources of arsenic in groundwaters. Geological constituents are therefore the only possible source of high arsenic concentrations. These facts, along with $\mathrm{Sr}$ isotopic analysis, indicate that arsenic in the Metro Manila groundwater is ultimately of volcanic origin. Higher arsenic concentrations are observed in the shallow groundwaters rather than in deep groundwaters (Fig. 3c). High arsenic-concentrations in pore waters in unconsolidated sediments in and around the shallow unconfined alluvium aquifers can mix more frequently with groundwater than in the deep confined groundwaters within the sediments of the Guadalupe Formation. The distribution of arsenic and the isotope ratios of sulfate and strontium suggest that the arsenic is dissolved from 
sedimentary deposits of volcanic origin without a significant contribution from changes in redox conditions in the aquifers.

\section{Conclusions}

Geochemical analysis and application of multi-isotope ratios $\left(\delta \mathrm{D}-\mathrm{H}_{2} \mathrm{O}\right.$ and $\delta^{18} \mathrm{O}-\mathrm{H}_{2} \mathrm{O}$, $\delta^{34} \mathrm{~S}^{-} \mathrm{SO}_{4}{ }^{2-}$ and $\delta^{18} \mathrm{O}-\mathrm{SO}_{4}{ }^{2-}$, and ${ }^{87} \mathrm{Sr} /{ }^{86} \mathrm{Sr}$ ) was performed to clarify fundamental aspects of groundwater quality in the Metro Manila region and to investigate contamination sources and mechanisms. Salinization and arsenic concentrations are the most important aspects of groundwater quality. High saline groundwaters with electrical conductivities up to $1,000 \mu \mathrm{S} / \mathrm{cm}$ are distributed in the coastal area of Manila Bay and in both shallow and deep aquifers of the plains area of the Pasig River. Arsenic is more enriched in the shallow groundwaters than in the deep groundwaters, and ca. 30\% of the analyzed groundwater samples $(n=28)$ have arsenic concentrations exceeding $10 \mu \mathrm{g} / \mathrm{L}$ (the maximum recommended WHO standard concentration).

The use of sulfate and strontium isotope tracers was successful in determining the contribution of man-made materials such as fertilizers and detergents to local-scale pollution in shallow groundwaters. These isotopes, together with geochemical measurements of the waters, also suggested that dissolved arsenic in the groundwaters was derived from sedimentary deposits of volcanic origin, and that changes in redox conditions were not responsible for arsenic dissolution into the water. Transfer of these contaminants from shallow to deep aquifers is not likely to be important because the mixing of these waters does not commonly occur in the Metro Manila region. Since multi-isotope ratios allow comprehensive understanding of water quality problems, the methodology used in this study can be applied in other Asian megacities.

\section{Acknowledgments}

We thank Peter Zamora and the other staff of the Geological Oceanography Laboratory of the Marine Science Institute, University of the Philippines for their field support and for supplying GIS data. Mr. Toshinori Kobayashi and Ms. Emi Kokado at RIHN kindly helped us to analyze strontium isotopic ratios. Two anonymous reviewers are kindly acknowledged for their useful comments on this paper. This study was funded by the Grant-in-Aid for Young Scientists (A) (no. 20681003), with additional support from the 'Human Impacts on Urban Subsurface Environments' Research Project at RIHN.

\section{References}

Åberg, G., Jacks, G., Hamilton, P.J., 1989. Weathering rates and ${ }^{87} \mathrm{Sr} /{ }^{86} \mathrm{Sr}$ ratios: an isotopic approach. J. Hydrol. 109, 65-78. 
ADB (Asian Development Bank), 2006. Asia water watch 2015. Published jointly by the Asian Development Bank (ADB), United Nations Development Programme (UNDP), United Nations Economic and Social Commission for Asia and the Pacific (UNESCAP), and World Health Organization (WHO).

Appelo, C.A.J., Postma, D., 2005. Ion exchange. In: Appelo, C.A.J., Postma, D. (Eds.), Geochemistry, groundwater and pollution. AA Balkema Publishers, Leiden, pp. 241-309.

Arthurton, R.S., 1998. Marin-related physical natural hazards affecting coastal megacities of the Asia-Pacific region-awareness and mitigation. Ocean \& Coastal Management 40, 65-85.

Banner, J.L., 2004. Radiogenic isotopes: systematics and applications to earth surface processes a chemical stratigraphy. Earth-Sci. Rev. 65, 141-194.

Borg, L.E., Banner, J.L., 1996. Neodymium and strontium isotopic constraints on soil sources in Barbados, West Indies. Geochim. Cosmochim. Acta 60, 4193-4206.

Brenot, A., Carignan, J., France-Lanord, C., Benoît, M., 2007. Geological and land use control on $\delta^{34} \mathrm{~S}$ and $\delta^{18} \mathrm{O}$ of river dissolved sulfate: The Moselle river basin, France. Chem. Geol. 244, 25-41.

Bullen, T.D., Krabbenhoft, D.P., Kendall, C., 1996. Kinetic and mineralogic controls on the evolution of groundwater chemistry and ${ }^{87} \mathrm{Sr} /{ }^{86} \mathrm{Sr}$ in a sandy silicate aquifer, northern Wisconsin. Geochim. Cosmochim. Acta 60, 1807-1821.

Böhlke, J.K., Horan, M., 2000. Strontium isotope geochemistry of groundwaters and streams affected by agriculture, Locust Grove, MD. Appl. Geochem. 15, 599-609.

Castillo, P.R., 1996. Origin and geodynamic implication of the Dupal isotopic anomaly in volcanic rocks from the Philippine island arcs. Geology 24, 271-274.

Clark, I.D., Fritz, P., 1997. Environmental isotopes in hydrogeology. Lewis Publishers.

Cook, P., Herczeg, A.L., 2000. Environmental tracers in subsurface hydrology. Kluwer Academic Publishers, USA.

Dogramaci, S.S., Herczeg, A.L., Schiff, S.L., Bone, Y., 2001. Controls on $\delta^{34} S$ and $\delta^{18} O$ of dissolved sulfate in aquifers of the Murray Basin, Australia and their use as indicators of flow processes. Appl. Geochem. 16, 475-488.

Ebarvia, M.C.M., 1997. Pricing for Groundwater Use of Industries in MetroManila, Philippines. International Development Research Centre, Ottawa, Canada.

Foster, S.S.D., Chlton, P.J., 2003. Groundwater: the process and global significance of aquifer degradation. Philosophical Transactions of the Royal Society of London Series B-Biological Sciences 358, 1957-1972.

Frost, C.D, Toner, R., 2004. Strontium isotopic identification of water-rock interaction and ground water mixing. Groundwater 42, 418-432.

Gosselin, D.C., Harvey, E.E., Frost, C., Stotler, R., Macfarlane, P.A., 2004. Strontium isotope 
geochemistry of groundwater in the central part of the Dakota (Great Plains) aquifer, USA. Appl. Geochem. 19, 359-377.

Grassi, S., Cortecci, G., 2005. Hydrogeology and geochemistry of the multilayered confined aquifer of the Pisa plain (Tuscany - central Italy). Appl. Geochem. 20, 41-54.

Hem, J.D., 1985. Study and interpretation of the chemical characteristics of natural water. US Geological Survey Water Supply Paper 2254.

Hosono, T., Ikawa, R., Shimada, J., Nakano, T., Saito, M., Onodera, S., Lee, K-K., Taniguchi, M., 2009. Human impacts on groundwater flow and contamination deduced by multiple isotopes in Seoul City, South Korea. Sci. Total Environ. 407, 3189-3197.

Hosono, T., Nakano, T., Igeta, A., Tayasu, I., Tanaka, T., Yachi, S., 2007. Impact of fertilizer on a small watershed of the Lake Biwa: use of sulfur and strontium isotopes as an environmental diagnosis. Sci. Total Environ. 384, 342-354.

JICA (Japan International Cooperation Agency), 1992. Study for the groundwater development in Metro Manila. JICA, Japan.

Katz, B.G., Bullen, T.D., 1996. The combined use of ${ }^{87} \mathrm{Sr} /{ }^{86} \mathrm{Sr}$ and carbon and water isotopes to study the hydrochemical interaction between groundwater and lakewater in mantled karst. Geochim. Cosmochim. Acta 60, 5075-5087.

Kendall, C., McDonnell, J.J., 1998. Isotope tracers in catchment hydrology. Elsevier Science B.V., The Netherlands.

Krouse, H.R., Mayer, B., 2000. Sulphur and oxygen isotope in sulphate. In: Cook, P., Herczeg, A.L. (Eds.), Environmental tracers in subsurface hydrology. Kluwer Academic Publishers, pp. 195-231.

Li, X-D., Masuda, H., Kusakabe, M., Ynagisawa, F., Zeng, H-A., 2006. Degradation of groundwater quality due to anthropogenic sulfur and nitrogen contamination in the Sichuan Basin, China. Geochem. J. 40, 309-332.

Lipfert, G., Sidle, W.C., Reeve, A.S., Ayuso, R.A., Boyce, A.J., 2007. High arsenic concentrations and enriched sulfur and oxygen isotopes in a fractured-bedrock ground-water system. Chem. Geol. 242, 385-399.

Moncaster, S.J., Bottrell, S.H., Tellam, J.H., Lloyd, J.W., Konhauser, K.O., 2000. Migration and attenuation of agrochemical pollutants: insights from isotopic analysis of groundwater sulphate. J. Contam. Hydrol. 43, 147-163.

MMDA and IAURIF (Metropolitan Manila Development Authority and Institute d'Aménagernent et d'Urbanisme de la Région Ile-de-France), 1997. Updating the land use map of metropolitan Manila through SPOT remote sensing imagery. MMDA and IAURIF.

Mukherjee, A., Sengupta, M.K., Hossain, M.A., Ahamed, S., Das, B., Nayak, B., Lodh, D., Rahman, M.M., Chakraborti, D., 2006. Arsenic contamination in groundwater: A global 
perspective with emphasis on Asian scenario. J. Health Population and Nutrition 24, 142-163.

Musgrove, M., Banner, J.L., 2004. Controls on the spatial and temporal variability of vadose dripwater geochemistry: Edwards Aquifer, central Texas. Geochim. Cosmochim. Acta 68, 1007-1020.

Na, C., Nakano, T., Tazawa, K., Sakagawa, M., Ito, T., 1995. A systematic and practical method of liquid chromatography for the determination of $\mathrm{Sr}$ and $\mathrm{Nd}$ isotopic ratios and REE concentrations in geological samples. Chem. Geol. 123, 225-237.

Nakano, T., Tayasu, I., Wada, E., Igeta, A., Hyodo, F., Miura, Y., 2005. Sulfur and strontium isotope geochemistry of trbutary rivers of Lake Biwa: implications for human on the decadal change of lake water quality. Sci. Total Environ. 345, 1-12.

Négrel, P., Allègre, C.J., Dupré, B., Lewin, E., 1993. Erosion sources determined by inversion of major and trace element ratios and strontium isotopic ratios in river water: the Congo Basin case. Earth Planet. Sci. Lett. 120, 59-76.

Otero, N., Soler, A., 2002. Sulphur isotopes as tracers of the influence of potash mining in groundwater Stalinization in the Llobergat Basin (NE Spain). Water Res. 36, 3989-4000.

Otero, N., Soler, A., Canals À., 2008. Controls of $\delta^{34} \mathrm{~S}$ and $\delta^{18} \mathrm{O}$ in dissolved sulphate: Learing from a detailed survey in the Llobregat River (Spain). Appl. Geochem. 23, 1166-1185.

Plant, J.A., Kinniburgh, D.G., Smedley, P.L., Fordyce, F.M., Klinck, B.A., 2005. Arsenic and Selenium. In: Lollar, B.S. (Ed.), Environmental geochemistry Vol. 9. In: Holland, H.D., Turekian, K.K. (Eds.), Treatise on geochemistry. Elsevier-Pergamon, Oxford, pp. 17-66.

Poage, M.A., Chamberlain, C.P., 2001. Empirical relationships between elevation and the stable isotope composition of precipitation and surface waters: Considerations for studies of paleoelevation change. Amer. J. Sci. 301, 1-15.

Polizzotto, M.L., Kocar, B.D., Benner, S.G., Sampson, M., Fendorf, S., 2008. Near-surface wetland sediments as a source of arsenic release to ground water in Asia. Nature 454, 505-509.

Rees, C.E., Jenkins, W.J., Monster, J., 1978. The sulfur isotopic composition of ocean water sulphate, Geochim. Cosmochim. Acta 42 377-381.

Robinson, B.W., Bottrell, S.H., 1997. Discrimination of sulfur source in pristine and polluted New Zealand river catchments using stable isotopes. Appl. Geochem. 12, 305-319.

Semhi, K., Clauer, N., Probst, J.L., 2000. Strontium isotope compositions of river water as records of lithology-dependent mass transfers: the Garonne river and its tributaries (SW France). Chem. Geol. 168, 173-193.

Smedley, P.J., Kinniburgh, D.G., 2002. A review of the source, behavior and distribution of arsenic in natural waters. Appl. Geochem. 17, 517-568. 
Spence, M.J., Bottrell, S.H., Thornton, S.F., Lerner, D.N., 2001. Isotopic modeling of the significance of bacterial sulphate reduction for phenol attenuation in a contaminated aquifer. Contam. Hydrol. 53, 285-304.

Stüben, D., Berner, Z., Chandrasekharam, D., Karmakar, J., 2003. Arsenic enrichment in groundwater of West Bengal, India: geochemical evidence for mobilization of As under reducing conditions. Appl. Geochem. 18, 1417-1434.

Thode, H.G., 1991. Sulphur isotopes in nature and the environment: Sulphur isotope in nature and the environment: an overview. In: Krouse, H.R., Grinenko, V.A. (Eds.), Stable isotopes-Natural and anthropogenic sulphur in the environment. SCOPE 43. Wiley, Chichester, pp. 1-26.

Torssander, P., Morth, C.M., Kumpulainen, R., 2006. Chemistry and sulfur isotope investigation of industrial wastewater contamination into groundwater aquifers, Pitea County, N. Sweden. J. Geochem. Explor. 88, 64-67.

Umezawa, Y., Hosono, T., Onodera, S., Siringan, F., Buapeng, S., Delinom, R., Yoshimizu, C., Tayasu, I., Nagata, T., Taniguchi, M., 2009. Tracing the sources of nitrate and ammonium contaminations in groundwater at developing Asian megacities, using GIS data and nitrate $\delta^{15} \mathrm{~N}$ and $\delta^{18} \mathrm{O}$. Sci. Total Environ. 407, 3219-3231.

Vitòria, L., Otero, N., Soler, A., Canals, A., 2004. Fertilizer characterization: isotopic data (N, S, O, C and Sr). Environ. Sci. Technol. 38, 3254-3262.

Yamanaka, M., Kumagai, Y., 2006. Sulfur isotope constraint on the provenance of salinity in a confined aquifer system if the southwestern Nobi Plain, central Japan. J. Hydrol. 325, 35-55.

\section{Figure Caption}

Fig. 1: Sampling locations on (a) a simplified geological map (after JICA, 1992) and (b) a land-use map (after MMDA and IAURIF, 1997) of Metro Manila.

Fig. 2: Piper diagram for water samples collected in Metro Manila.

Fig. 3: Maps showing the distribution of (a) electrical conductivity, (b) nitrate ion concentration, and (c) arsenic concentrations for water samples collected in Metro Manila. The distribution of high electrical conductivity $(>1,000 \mu \mathrm{S} / \mathrm{cm})$ among 90 deep groundwater samples measured in 1991 (JICA, 1992) is also shown in a gray color.

Fig. 4: $\delta \mathrm{D}-\mathrm{H}_{2} \mathrm{O}$ vs. $\delta^{18} \mathrm{O}-\mathrm{H}_{2} \mathrm{O}$ diagram for water samples collected in Metro Manila. Best fitted line and weighted mean isotope compositions of eighty-four precipitation data during 1961 and 2003 in Metro Manila plain areas (Global Network of Isotopes in Precipitation) are also shown.

Fig. 5: $\delta^{34} \mathrm{~S}_{-} \mathrm{SO}_{4}{ }^{2-}$ vs. $\mathrm{SO}_{4}{ }^{2-}$ concentration diagram for water samples collected in Metro Manila. (a) Data for sea water (Rees et al., 1978; Hem, 1985), water reacted with chemical fertilizers 
(this study), and water reacted with synthetic detergents (this study) are also shown for comparison. The marked crosses indicate the average compositions of possible source materials. (b) Numbers in the plots indicate the sample numbers. Three solid lines indicate the simple mixing line connecting upstream water of the Pasig River tributary (sample M11:

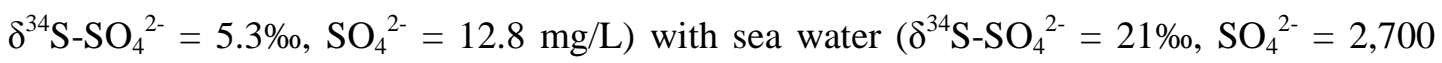
$\mathrm{mg} / \mathrm{L}$ ), average compositions $(n=3)$ of water reacted chemical fertilizers (Table 2; $\delta^{34} \mathrm{~S}^{-\mathrm{SO}_{4}{ }^{2-}=0.2 \%}$, $\left.\mathrm{SO}_{4}{ }^{2-}=542 \mathrm{mg} / \mathrm{L}\right)$, and with average compositions $(n=4)$ of water reacted synthetic detergents $\left(\delta^{34} \mathrm{~S}_{-} \mathrm{SO}_{4}{ }^{2-}=19.2 \%\right.$, $\left.\mathrm{SO}_{4}{ }^{2-}=263 \mathrm{mg} / \mathrm{L}\right)$, respectively. Numbers along the mixing lines represent the relative contribution of each source material in percentages. The compositional field enclosed by the dotted line represents the original groundwater compositions before the occurrence of sulfate reduction (see text for details).

Fig. 6: $\delta^{34} \mathrm{~S}^{-\mathrm{SO}_{4}{ }^{2-}}$ vs. $\delta^{18} \mathrm{O}-\mathrm{SO}_{4}{ }^{2-}$ diagram for water samples collected in Metro Manila. Numbers in the plots indicate the sample numbers. Data for sea water (Rees et al., 1978; Krouse and Mayer, 2000), soil sulfate (Krouse and Mayer, 2000), water reacted chemical fertilizers (this study), and water reacted synthetic detergents (this study) are also shown for comparison. The marked crosses indicate the average compositions of possible source materials. The three solid lines and the compositional field enclosed by the dotted line mean the same as in Fig. 5.

Fig. 7: $\delta^{34} \mathrm{~S}_{-} \mathrm{SO}_{4}{ }^{2-}$ vs. ${ }^{86} \mathrm{Sr} /{ }^{87} \mathrm{Sr}$ diagram for water samples collected in Metro Manila. Numbers in the plots indicate the sample numbers. Data for sea water is from Rees et al. (1978) and Banner (2004) for $\delta^{34} \mathrm{~S}_{-} \mathrm{SO}_{4}{ }^{2-}$ and ${ }^{86} \mathrm{Sr} /{ }^{87} \mathrm{Sr}$, respectively. Compositional ranges of ${ }^{86} \mathrm{Sr} /{ }^{87} \mathrm{Sr}$ ratios for volcanic rocks in Metro Manila region and European fertilizers and detergents are from Castillo (1996) and Vitòria et al. (2004), respectively.

\section{Table Captions}

Table 1: Analytical results for water samples from Metro Manila, collected between 26 and 30 May, 2006

Table 2: Analytical results for water samples reacted with chemical fertilizers and detergents used in Metro Manila 
Fig. 1

a)

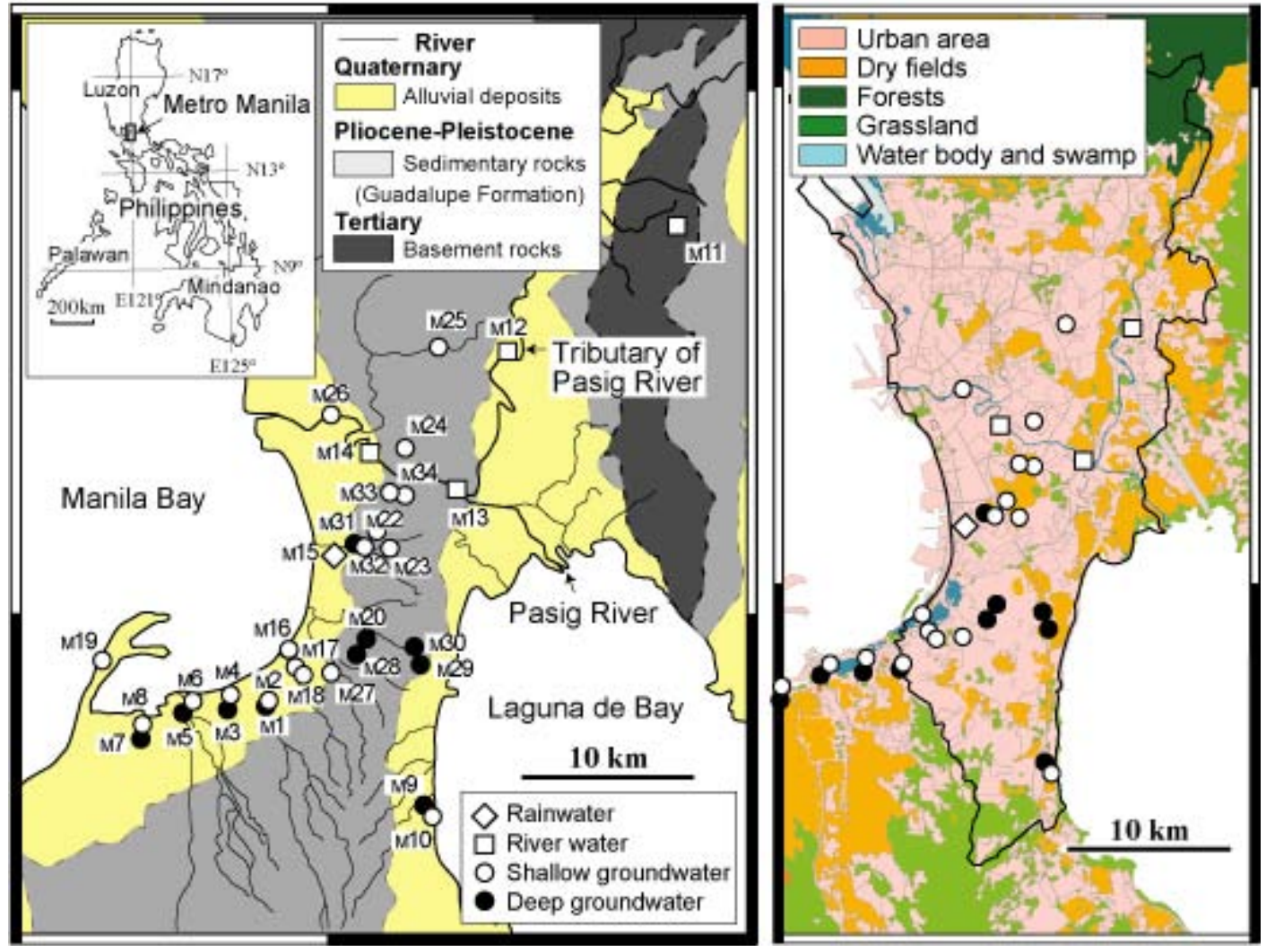

b) 
Fig. 2

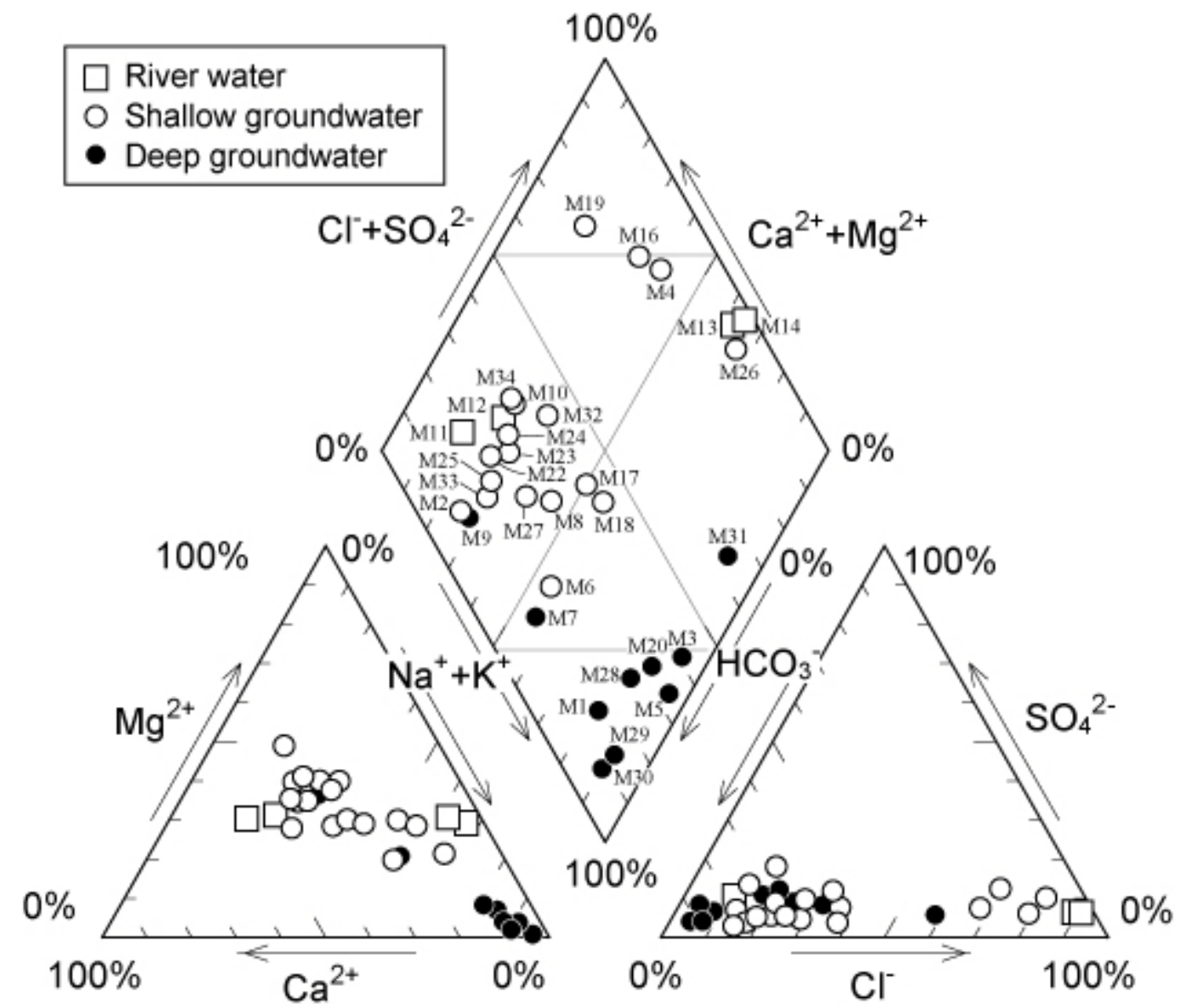


Fig. 3
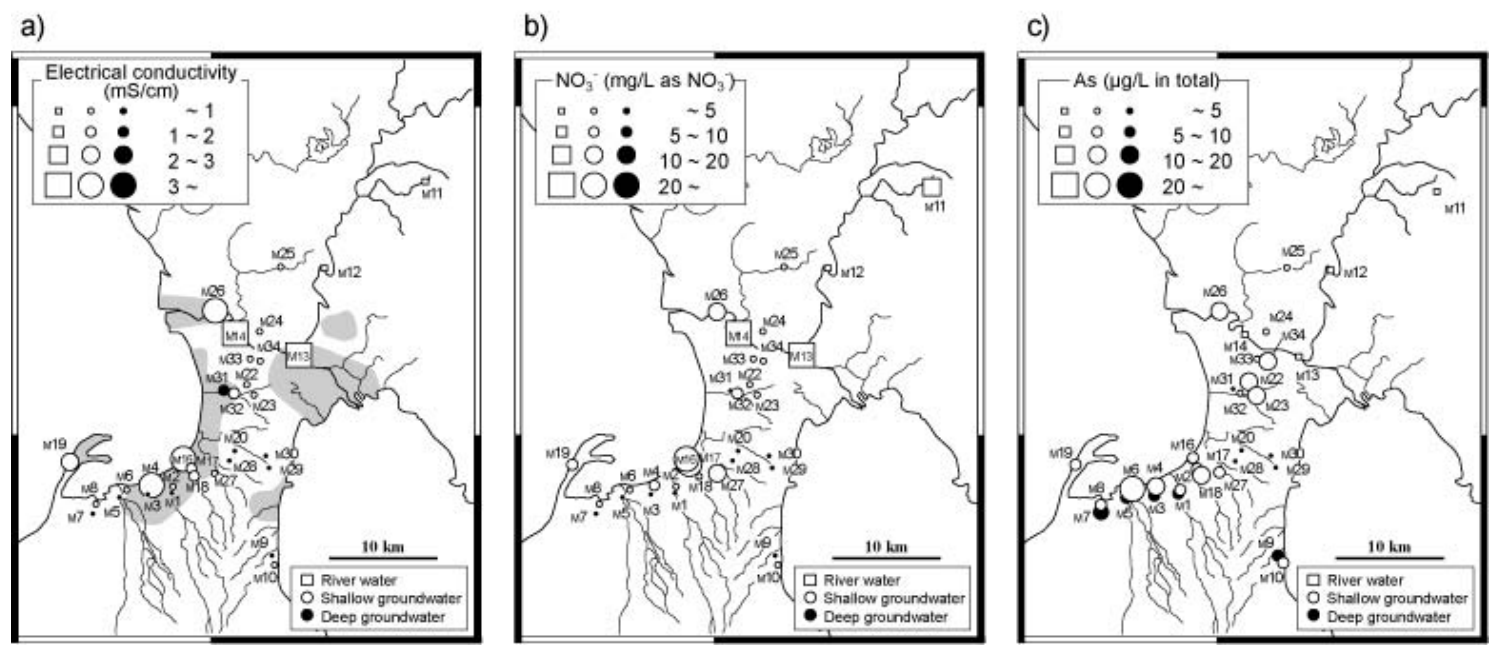
Fig. 4

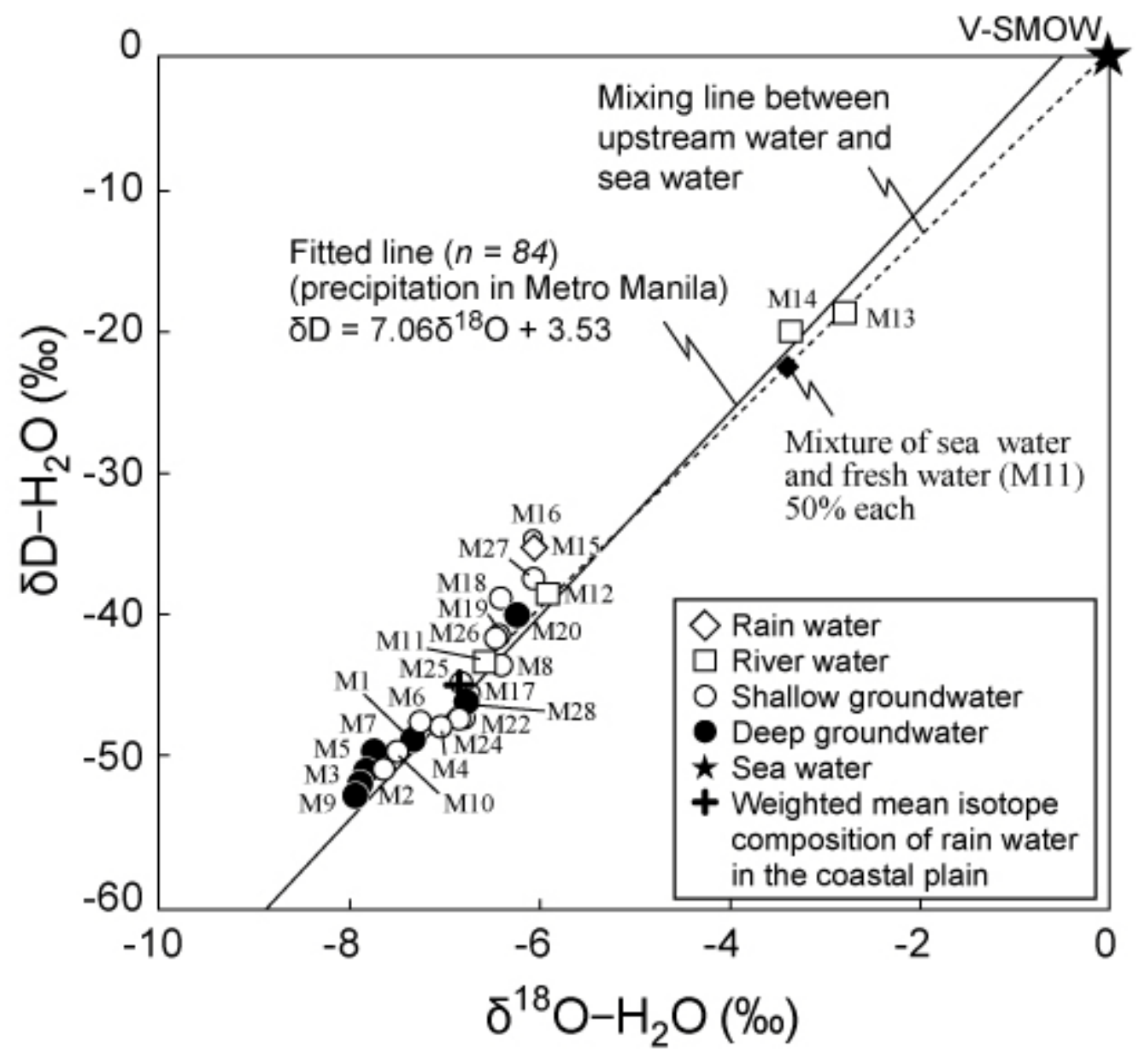


Fig. 5
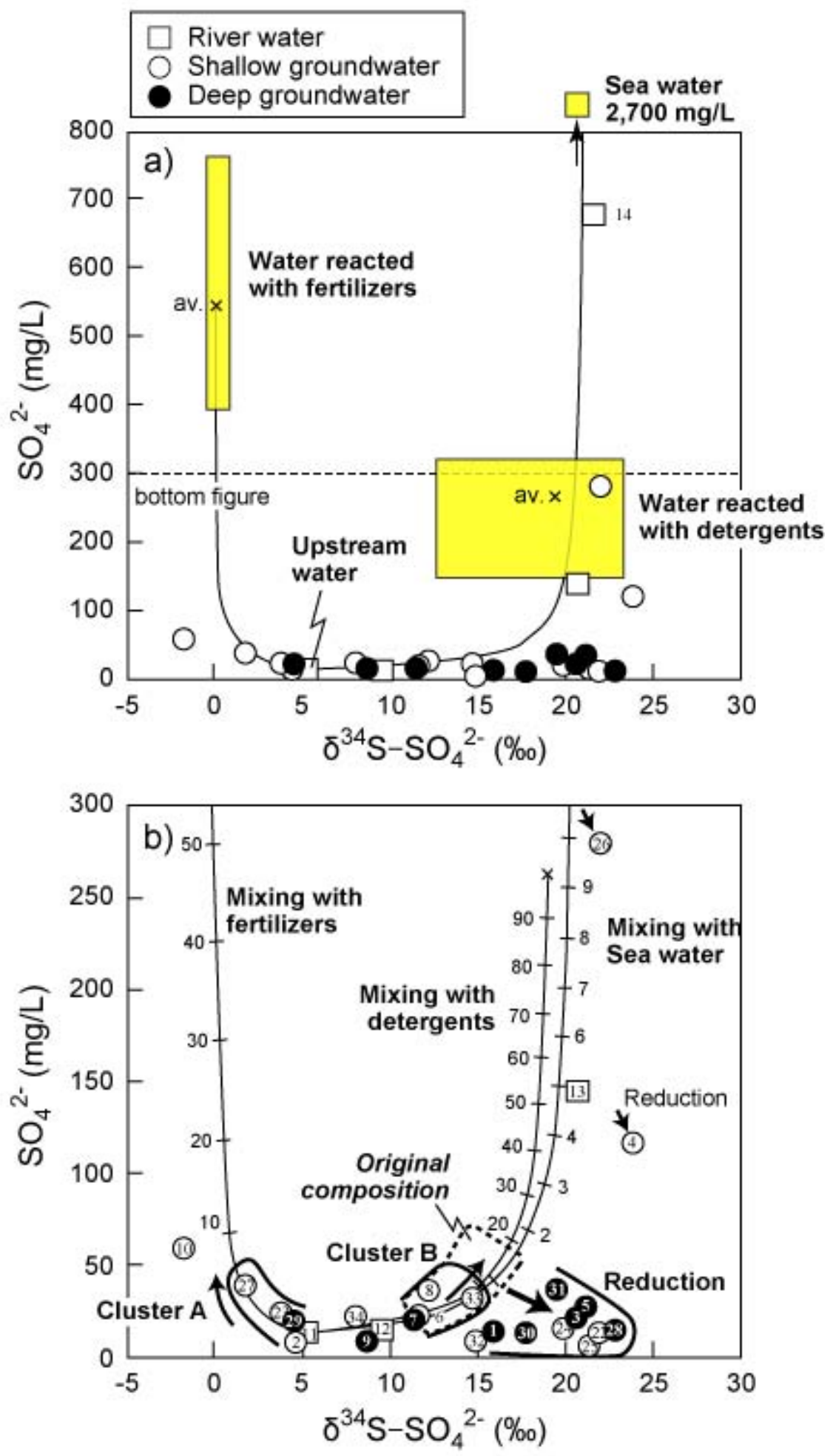
Fig. 6

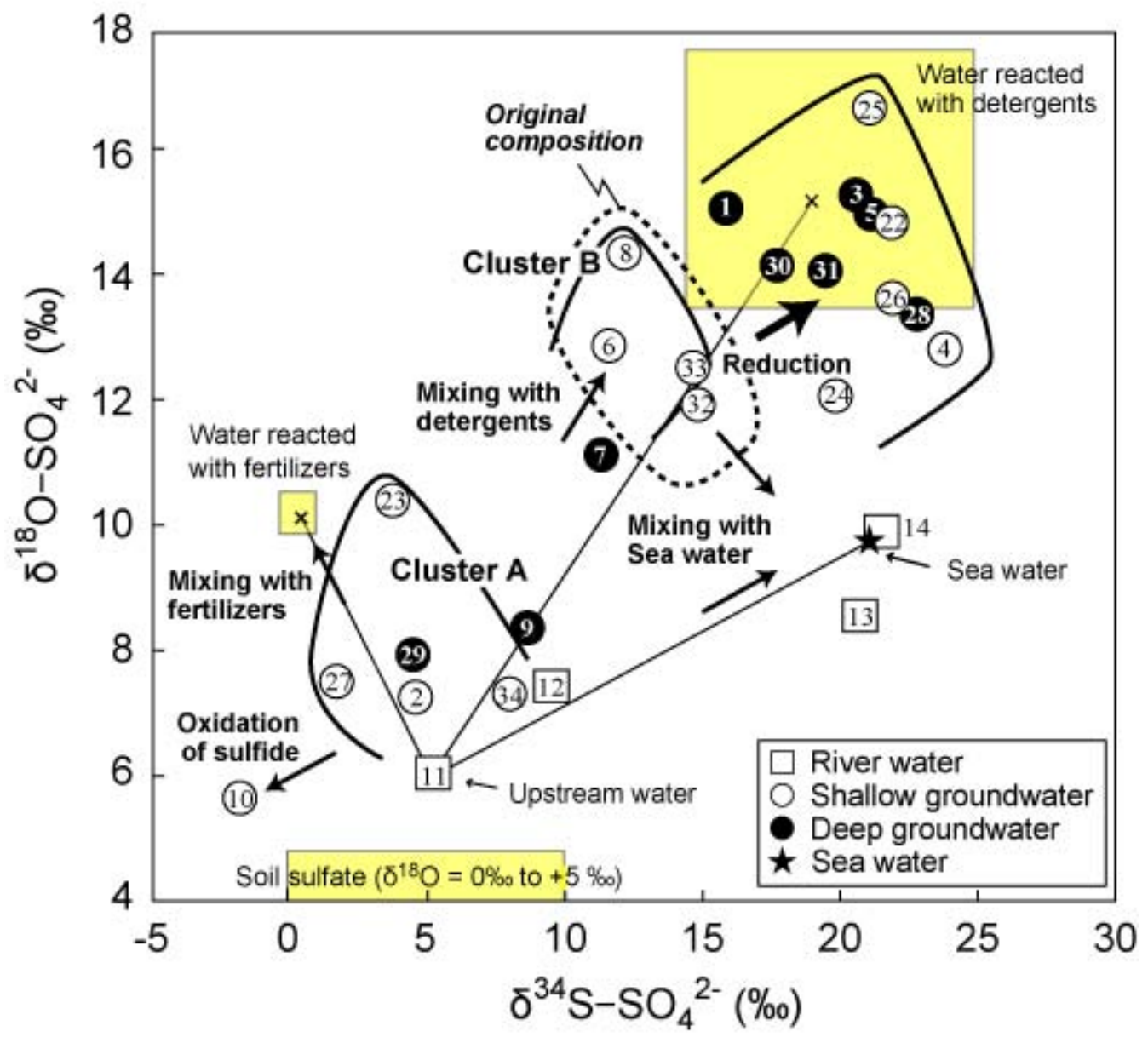


Fig. 7

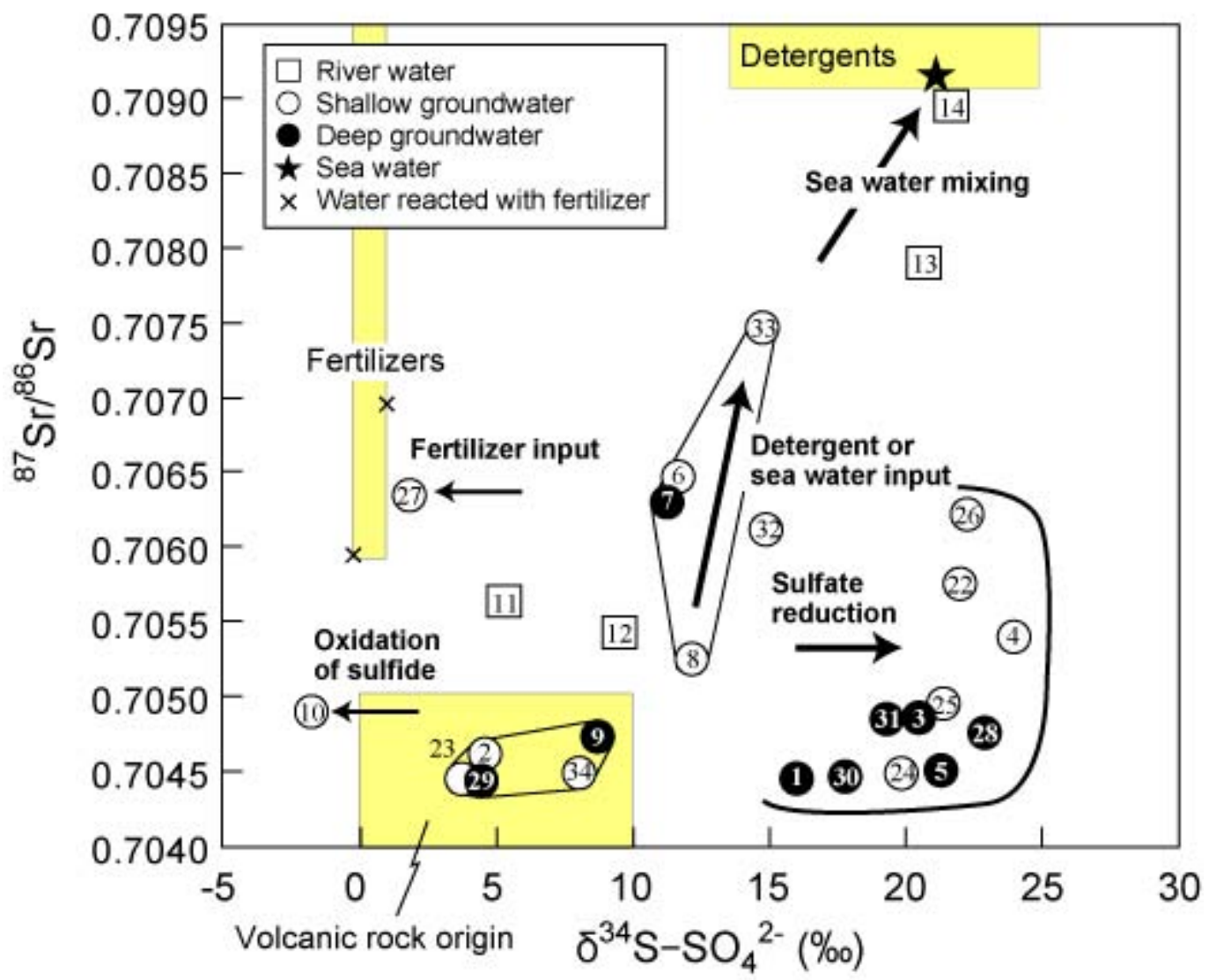

